Institute of $\mathbf{F}_{\text {ood and }} \mathbf{A}_{\text {gricultural }} \mathbf{S}_{\text {ciences }}$

\title{
Water Resources for Florida Citrus $\mathbf{1}$
}

\section{Brian Boman and Larry Parsons ${ }^{2}$ \\ Introduction}

Water is one of Florida's most valuable

resources. It is generally abundant, as the state typically receives about 175 billion gallons per day (150 bgd in rainfall and 25 bgd inflow from Georgia and Alabama). Fresh water supplies come from extensive subsurface beds of porous rock (aquifers) and from fresh water lakes, streams and reservoirs. Florida's aquifers contain more than a quadrillion gallons of water, which is 30,000 times the average daily discharge of Florida's 13 largest rivers.

There is, however, a tremendous variability in the source of supply (rainfall). Most of the potential supply must be left in the hydrologic system for nonconsumptive uses such as navigation, recreation, and aesthetics, or to provide a habitat for fish and wildlife, or because it cannot be economically used. In addition, water is not evenly distributed in the state. The densely populated coastal areas of the peninsula have much less available water than interior, northern regions. Thus, the potential for conflict over the allocation of water is a growing concern in Florida.
Withdrawal of water for consumptive use continues to rise. More than $50 \%$ of the total fresh water used in Florida comes from groundwater, and more than $90 \%$ of the public rely on groundwater supplies for their drinking water. Of all the fresh water withdrawn in Florida, only about one-third is consumed by evaporation, transpiration, or production processes. The remaining two-thirds are returned to the environment, either to surface streams or to aquifers.

\section{Groundwater and the Hydrologic Cycle}

The continuous circulation of water from land and sea to the atmosphere and back again is called the hydrologic cycle (Fig. 1). Inflow to the hydrologic system is primarily rainfall. Outflow occurs as runoff, evaporation, transpiration by plants, and outflow from groundwater into wells, rivers, springs or oceans.

Components of the hydrologic cycle include evaporation, transpiration, condensation, precipitation, interception, infiltration, percolation, runoff and storage. Brief descriptions of these processes follow:

1. This is document No. CH162 and Circular 1420, one of a series of the Agricultural and Biological Engineering Department, Florida Cooperative Extension Service, Institute of Food and Agricultural Sciences, University of Florida. Publication date: August 2002. Please visit the EDIS Web site at http://edis.ifas.ufl.edu for additional publications related to citrus water management. This document can be accessed as http://edis.ifas.ufl.edu/CH162.

2. Brian Boman, Associate Professor, Department of Agricultural and Biological Engineering, Indian River REC-Ft. Pierce; and Larry Parsons, Professor, Horticultural Sciences Department, Citrus REC-Lake Alfred. University of Florida Cooperative Extension Service, Institute of Food and Agricultural Sciences, Gainesville, FL 32611.

The Institute of Food and Agricultural Sciences is an equal opportunity/affirmative action employer authorized to provide research, educational information and other services only to individuals and institutions that function without regard to race, color, sex, age, handicap, or national origin. For information on obtaining other extension publications, contact your county Cooperative Extension Service office. Florida Cooperative Extension Service/Institute of Food and Agricultural Sciences/University of Florida/Christine Taylor Waddill, Dean. 


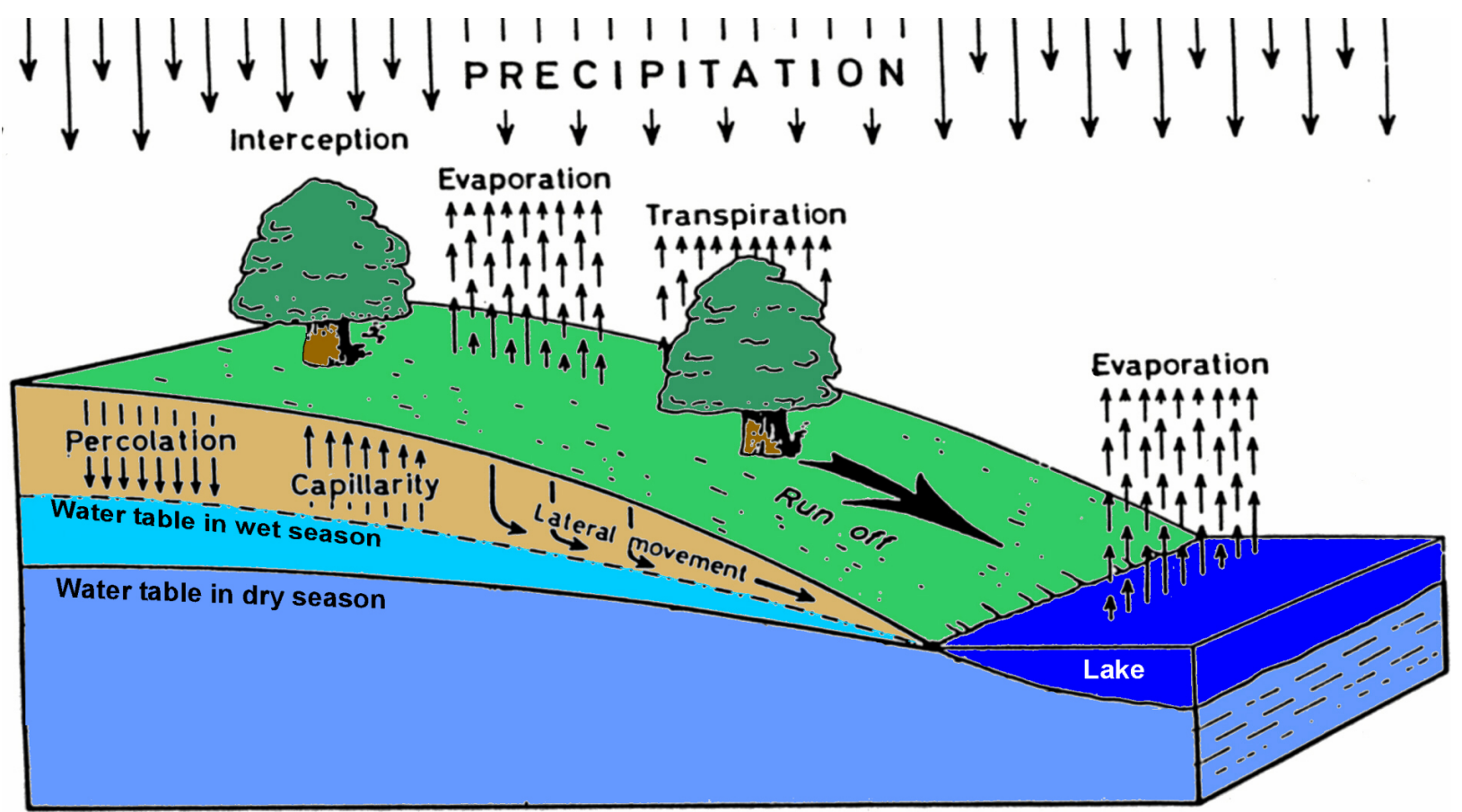

Figure 1. Typical water cycle under Central Florida conditions (adapted from Fitzpatrick, 1974).

\section{$\underline{\text { Evaporation }}$}

The change of water from a liquid to a gaseous state is called evaporation. Evaporation rate is affected by solar radiation, air temperature, vapor pressure, wind, and atmospheric pressure.

Evaporation occurs from raindrops, free water surfaces, such as seas and lakes, water settled on vegetation and soil, and from human activities. During evaporation, moisture is moved into the atmosphere as water vapor.

\section{$\underline{\text { Condensation }}$}

The change of water from a vapor to a liquid state is termed condensation. Water vapor condenses onto small airborne particles to form dew, fog, and clouds. Condensation occurs when the temperature drops to the dew point temperature or when the amount of vapor in the air is increased to the water vapor saturation point.

\section{$\underline{\text { Precipitation }}$}

The fall of water particles from the atmosphere to the ground is precipitation. It occurs in two forms. In the coalescence subprocess, a larger lead drop, that reaches a critical size in the air, attracts a number of smaller drops to create precipitation. In the ice-crystal subprocess, ice develops under freezing temperatures in clouds and attracts water droplets that evaporate and condense on the crystals. Precipitation may fall onto both bodies of water and land.

\section{$\underline{\text { Interception }}$}

The interruption of the movement of water on the land surface is called interception. It takes place by vegetation or through storage in canals, reservoirs, and lakes. In addition, rainwater is stored on the surface of leaves and other organic materials up to their maximum storage capacity, above which the excess water falls to the ground. Water is also intercepted through evaporation.

\section{$\underline{\text { Infiltration }}$}

The movement of water from the air into the soil surface is called infiltration. The amount of water transfer depends on the texture and structure of the soil, the soil moisture content, and the atmospheric concentration of water.

\section{$\underline{\text { Percolation }}$}


Percolation is the movement of water through the soil by gravity and capillary forces. Water in the zone of aeration is called vadose water. Water in the zone of saturation is called groundwater. The two zones meet at the water table. Percolation contributes to both underground water storage and to water movement.

\section{$\underline{\text { Transpiration }}$}

The transfer of water from plants to the atmosphere as vapor through leaf openings is called transpiration. The amount of transpiration depends on the plant species and the amount of light exposure, temperature, humidity, wind, and time of year. Transpiration increases movement of water to the atmosphere. Aeas that have healthy plants that shade the ground will have increased transpiration and reduced soil evaporation compared to areas with bare soil.

\section{$\underline{\text { Runoff }}$}

The flow of water from drainage basins to surface streams is runoff. It occurs in three main forms. Surface runoff takes place on the land surface through both natural and manmade channels. Subsurface runoff occurs from water that has infiltratrated and moves laterally into canals and ditches. Groundwater runoff results from water percolates into the water table and moves with the general flow of the water table.

\section{Storage}

Water is naturally stored in the atmosphere, on the surface of the earth, and in the ground. Water movement though surface and ground storage depends on the geologic features of the storage locations.

\section{Vadose Zone}

Between the land surface and the water table is the unsaturated (vadose) zone where both water and air occur in the soil pores. Water in the unsaturated zone is either taken up by plants, evaporated, or drained by gravity into the saturated zone. In the flatwoods soils of Florida, the unsaturated zone is typically only the top 10 to 40 inches of the soil profile during the dry season, and it may be non-existent during the wet season when the water table is at or above the ground surface. In the sandy soils of the Central Florida Ridge, however, the vadose zone can extend to a depth of 100 feet or more.

\section{Groundwater Zone}

In the saturated groundwater zone (water table), all pores and crevices are filled with water, and all of the air has been forced out. Water seeping into this zone is called recharge. Groundwater can occur either as an unconfined (phreatic) aquifer or as a confined (artesian) aquifer. In an unconfined aquifer, the water table forms the upper boundary of the aquifer, and the water level in a well will rest at this level. Water infiltrating from the surface has the potential to move rapidly into an unconfined aquifer; thus, there is potential for contamination from surface activities. In an unconfined aquifer, groundwater moves by gravity from areas of high water table elevation to areas of lower water table elevation.

Confined aquifers (Fig. 2) are overlain by an impermeable, or semipermeable confining layer, and are typically under pressure. Therefore, the level to which water will rise in a tightly cased well is above the top of its upper confining layer (artesian well). If the water level rises above the land surface, it is called a flowing artesian well.

Water in confined aquifers moves from areas of high potentiometric head (as measured by the level to which water will rise in a tightly cased well) to areas of low potentiometric head. Confined aquifers are less susceptible to contamination from local surface activities because infiltrating water typically moves very slowly through the confining layer. However, the confining layers may be fractured and missing in many places. Thus, contaminated water may move horizontally on top of the confining layer for some distance before entering the confined aquifer through a breach in the confining layer.

\section{Major Florida Aquifers}

The most important aquifers that yield large quantities of water to wells, streams, lakes, and springs in Florida are shown in Fig. 3. The primary source of groundwater for most of the state is the 


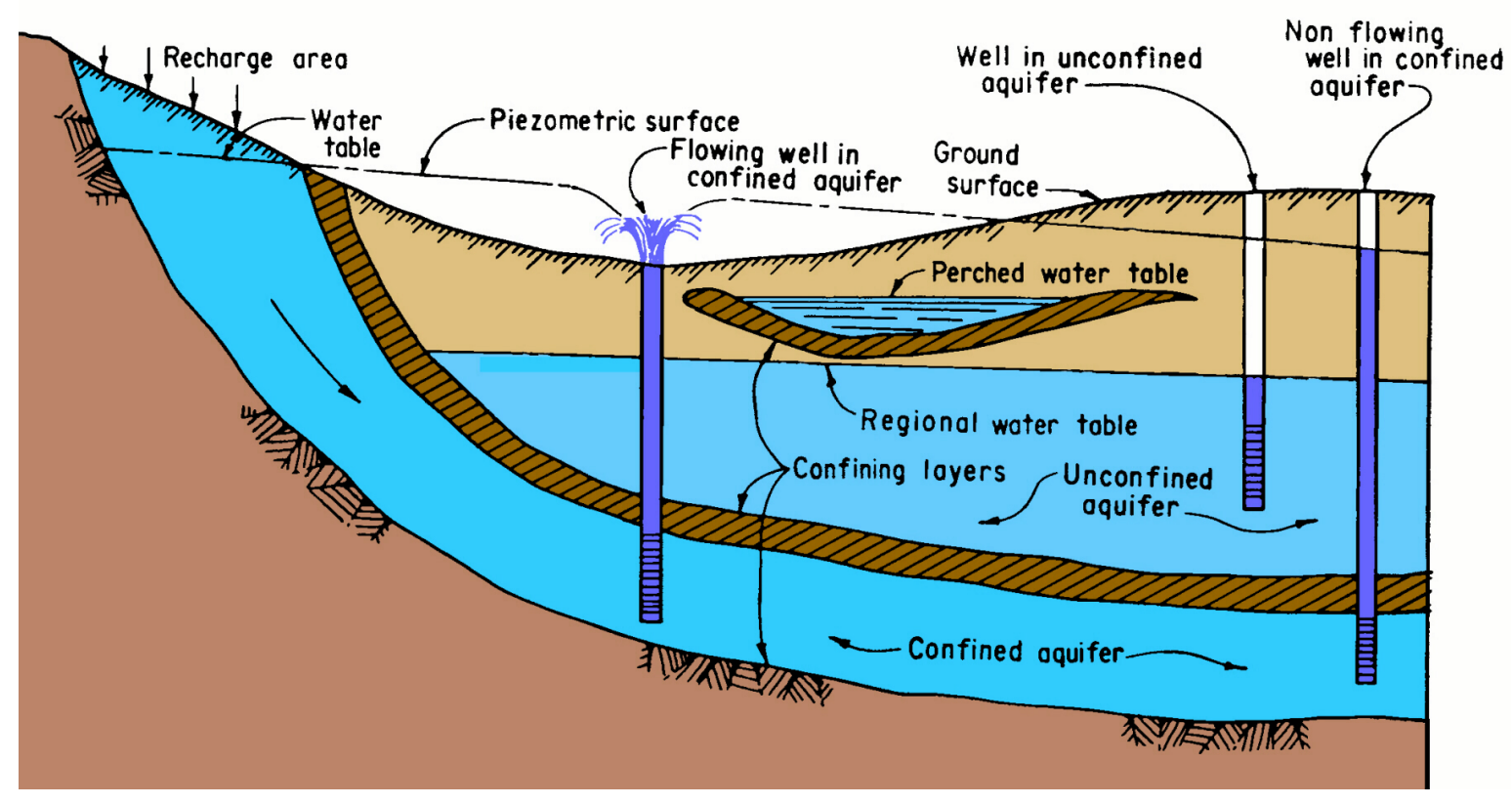

Figure 2. Typical hydrogeology of the surficial water table aquifier and the confined Floridian Aquifier system (with artesan wells) in South Florida.

Floridan aquifer. In coastal areas and in South Florida, the top of the Floridan Aquifer is often several hundered feet below the surface, and it underlies surficial aquifers. The Floridan is one of the most productive aquifers in the United States.

However, in many areas Floridan Aquifer wells have high salinity levels, making them undesirable for citrus irrigation.

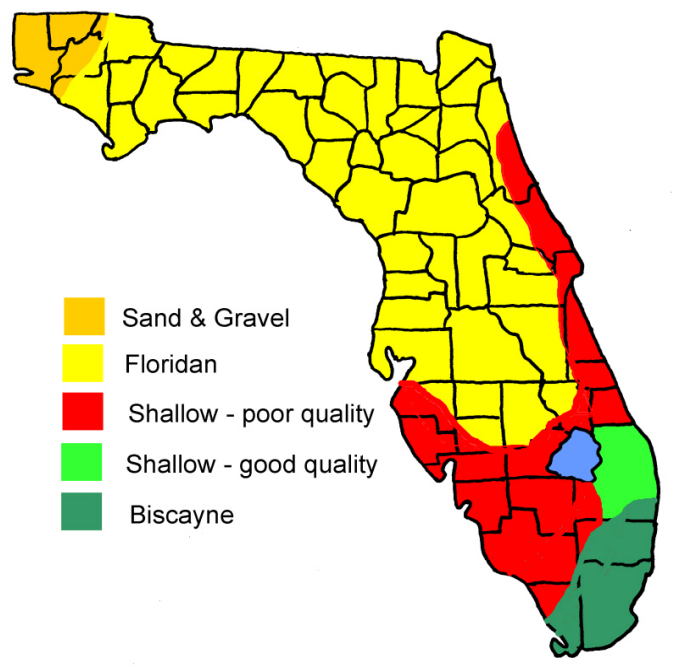

Figure 3. Major groundwater aquifers used for irrigaion in Florida.

In many areas, the Floridan Aquifer is confined by low permeability sediments of the Hawthorne formation (Fig. 4). The Hawthorne formation is absent in the north central part of the state along the Ocala Uplift. In this area the aquifer is unconfined, and thus receives recharge from water infiltrating from the surface.

The origin of subsurface flow to the Floridan Aquifer in northern Florida is from Alabama and Georgia. In peninsular Florida, subsurface Floridan flow originates in the Central Uplands of the state. In many coastal areas, the potentiometric surface (water level in a tightly cased well) is above the land surface; thus artesian flow occurs in wells or along geologic openings (springs).

The unconfined Biscayne aquifer underlies an area of about 3,000 square miles in Dade, Broward, and Palm Beach Counties. This aquifer is 100 to 400 feet thick near the coast, but thins to a thickness of only a few feet further inland. Water in the Biscayne aquifer is derived chiefly from local rainfall. However, during dry periods recharge can come from canals linked to Lake Okeechobee. A shallow, unconfined aquifer is present over much of the state, but in most areas it is not an important source of groundwater because a better supply is available from other aquifers. However, where water requirements are small, this aquifer is tapped by small diameter wells. In South Florida the shallow aquifer is a major source of groundwater in Martin, Palm Beach, 


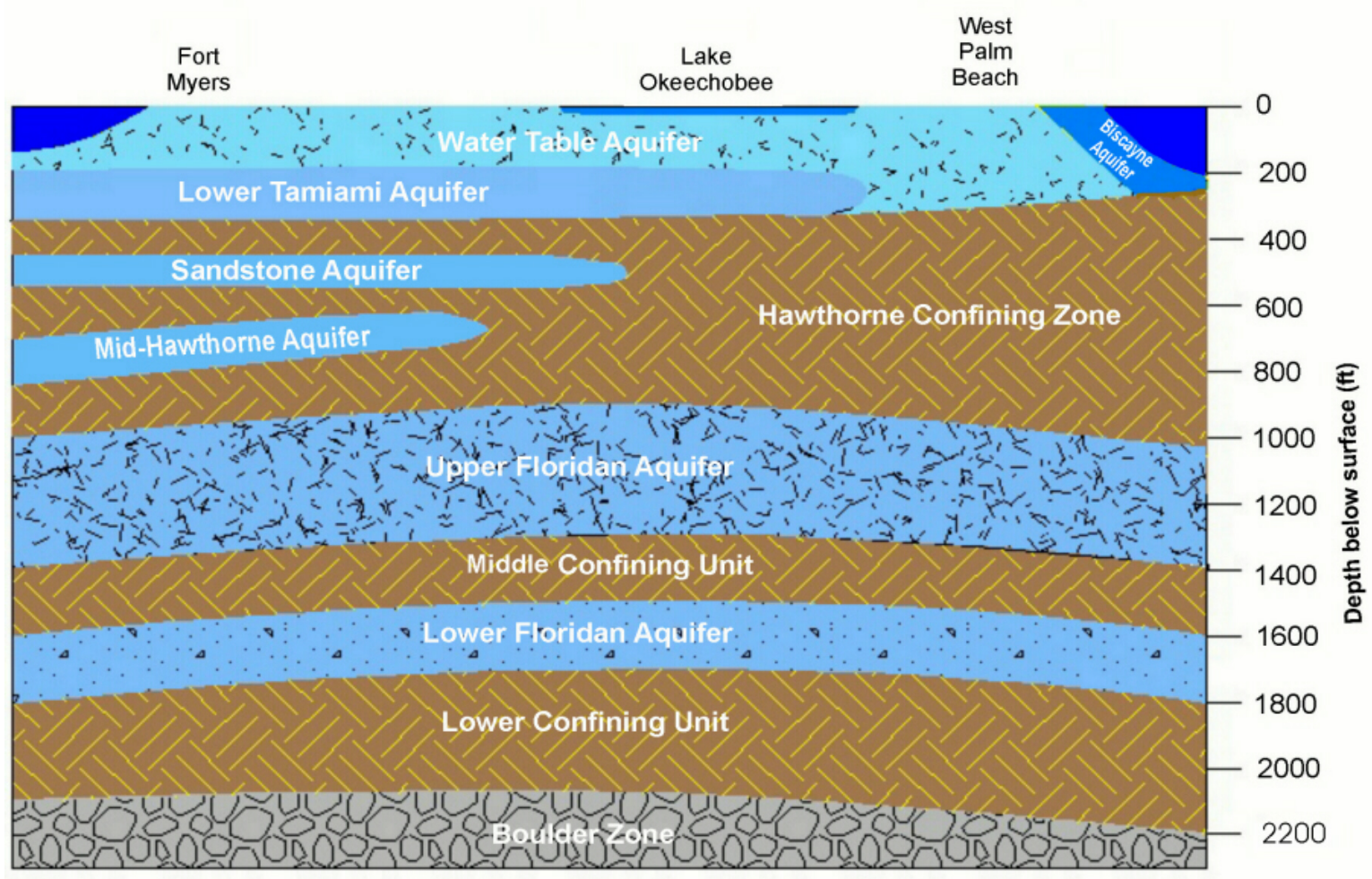

Figure 4. Generalized cross section of hydrogeology in South Florida.

Hendry, Lee, Collier, Indian River, St. Lucie, Glades and Charlotte Counties. The water in this shallow aquifer is derived primarily from local rainfall.

\section{Sources of Groundwater Contamination}

Florida's unique hydrogeologic features of a thin soil layer, high water table, porous limestone, and large amounts of rainfall, coupled with its rapid population growth, result in a groundwater resource extremely vulnerable to contamination. Nonpoint sources, which have potential for contributing to groundwater contamination, include coastal saltwater bodies, urban storm water, agricultural practices, and mining.

Since Florida is peninsula between two bodies of salt water, there is a potential for salt water intrusion into the fresh groundwater supply. Salt water is more dense than fresh water and thus exerts a constant pressure to flow into the fresh water aquifers. As long as fresh water levels in the aquifer are above sea level, the fresh water pressure limits the inland movement of the salt. Overpumping of coastal wells, however, can increase salt water intrusion. If water is pumped out faster than the aquifer is replenished, the pressure of the fresh water is decreased. This causes the level at which the salt water and fresh water meet to rise in the aquifer, degrading the fresh water quality. The problem of salt water intrusion is aggravated by periods of drought during which there is not enough rainfall to replenish the fresh water aquifers.

Figure 5 shows areas of Florida where the Floridan Aquifer which contain chloride concentrations greater than $250 \mathrm{mg} / \mathrm{l}$. In South Florida, where the Floridan Aquifer is artesian and underlies the Biscayne and shallow aquifers, its saline water may recharge the overlying fresh water aquifers, increasing their salt content. This type of recharge may occur naturally by upward seepage through the confining layer or it may be increased by flowing artesian wells.

\section{Reclaimed Water Use on Citrus}

The main studies using reclaimed municipal wastewater to irrigate young and mature orange and grapefruit trees in Florida have been conducted at the Water Conserv II project near Orlando and at a citrus 


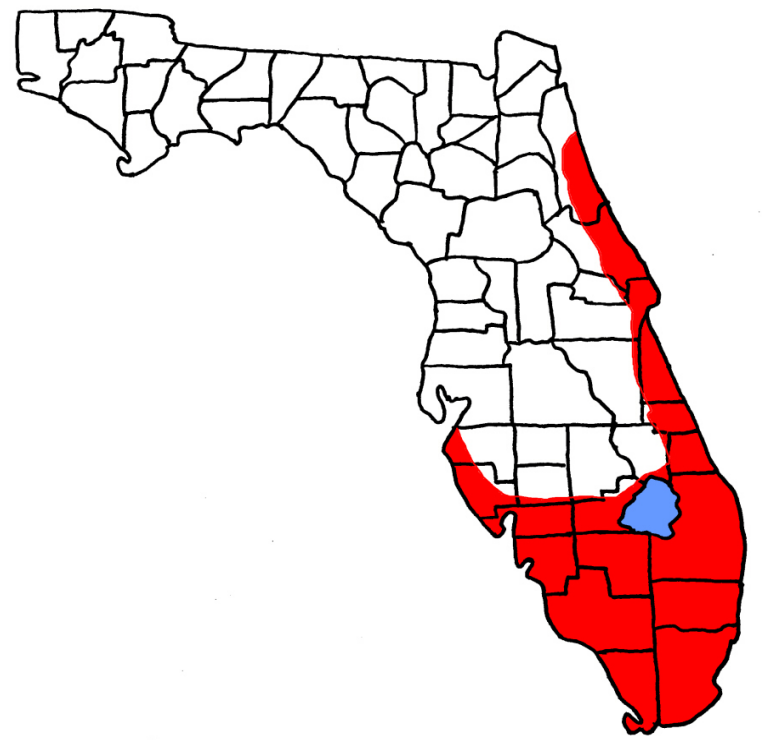

Figure 5. Shaded areas are general locations where the Floridan Aquifer contains more than 250 ppm Cl.

grove adjacent to an Indian River County wastewater treatment plant near Vero Beach. Other smaller reclaimed water facilities are located in Pasco, Polk, Manatee, Sarasota, and Okeechobee Counties and involve primarily individual growers and local treatment facilities.

The Water Conserv II project provides citrus growers with a long-time source of reclaimed water (20-year contract) to be used for irrigation of young and mature citrus trees. Water is provided free, although growers must absorb costs associated with connection to the system and purchase of water meters. Growers have the option of refusing water four weeks per year, but only two weeks consecutively. Water that is not applied to groves during high rainfall periods is diverted to rapid infiltration basins (RIBs), where it percolates through the sand and eventually reaches the aquifer. Water quality is regulated very strictly. The water may not have detectable levels of fecal coliforms or viruses and must have $<30 \mathrm{mg} / \mathrm{L}$ biochemical oxygen demand (BOD) and $25 \mathrm{mg} / \mathrm{L}$ total suspended solids (TSS).

In the Water Conserv II study, trees receiving reclaimed wastewater had similar or greater yields and improved tree vigor compared to trees receiving well water. High application rates of reclaimed water (100 inches per year) decreased acid, juice content, and soluble solids (Brix and solids per box). By reducing water stress, high application rates of reclaimed water promoted greater canopy growth and yield.

In contrast, tree vigor and fruit quality were not different for mature grapefruit trees which received reclaimed water or canal water growing in the flatwoods area near Vero Beach. Yields, however, were higher for the reclaimed water treatments in one season, but the effect was variable. No adverse effects of applying high levels of reclaimed water were noted at either site.

The composition of reclaimed municipal wastewater at the Water Conserv II and Indian River County sites varied through the season. Water from both sites was low in heavy metals, reflecting the urban nature and lack of heavy industry in these areas. The water at both sites was quite similar in most characteristics, with the exception of significantly higher sodium, chloride, magnesium, and boron levels at the Vero Beach facility. After 12 years at Conserv II and 3 years at Vero Beach, no adverse effects on tree growth and development or yields have been observed related to elevated levels of these elements.

The reclaimed water provided some nutritional value from constituents that wasn't removed in the treatment process. These nutrients were present at low levels. However, when reclaimed water was applied at high rates (1-1.5 inches per week) in order to dispose of as much water as possible per unit of land area, the cumulative amount of the nutrients applied can be significant. Therefore, rates of nitrogen, phosphorus, and potassium fertilizers applied by traditional methods may often be reduced. For example, about $65 \%$ of the nitrogen needed to produce a fresh grapefruit crop in the Indian River area was applied with the reclaimed water at the Vero Beach site. Considerable amounts of phosphorus and potassium were also provided by the reclaimed water at both sites.

\section{Horizontal Wells}

In recent years, horizontal wells (Fig. 6) have become an economical water supply alternative for areas with shallow watertables. Horizontal wells have been installed as primary water supplies for golf 
courses, citrus groves, ornamental nurseries, commercial landscapes, and vegetable farms. Traditional water supplies for these operations have come from deep aquifers.

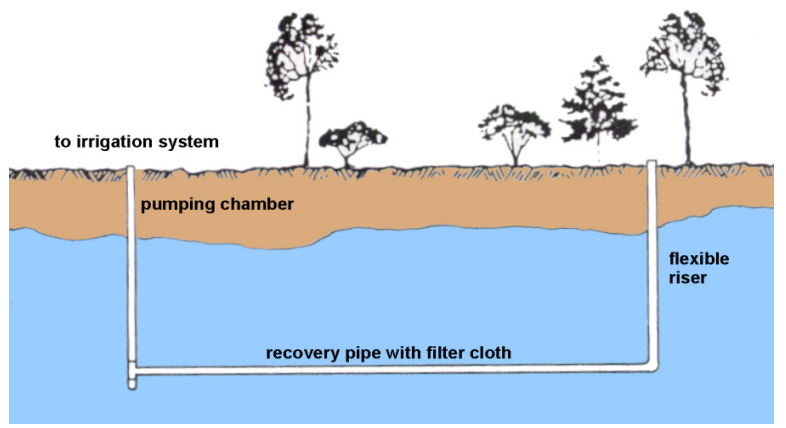

Figure 6. Schematic diagram of horizontal well installation.

Concerns about slow recharge and aquifer depletion in the deep aquifers have made it difficult to get permits to use this water in many areas. In addition water withdrawn from deep wells in the Floridan Aquifer is often highly mineralized and poorly suited for irrigation purposes. In contrast, the surfical aquifers generally have much less mineralization and have rapid recharge rates. The lower aquifer transmissivity and large drawdown caused by high-volume conventional vertical wells make tapping this resource unfeasible in many areas.

Horizontal wells typically utilize 6 to 10 inch diameter perforated drain (recovery) pipe installed 15-20 feet below the ground surface. Due to the high cost of installation, horizontal wells have traditionally been reserved for high-value projects where wells were installed to drop and/or maintain a lowered water table for construction purposes. However, recently developed installation machinery has made the cost of horizontal wells competitive with other water supply sources.

\section{$\underline{\text { Horizontal Well Installation }}$}

The current technology allows extraction from groundwater aquifers at depths to about 25 feet. The installation machine digs the trench, lays the recovery pipe, places drain envelope media (if required), and backfills in one operation (Fig. 7).

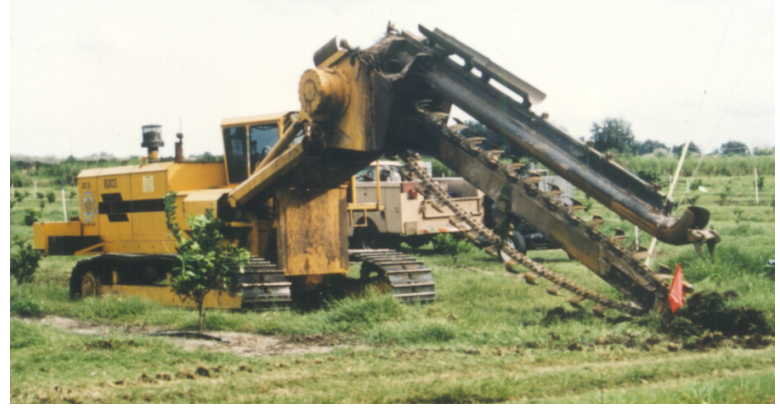

Figure 7. Horizontal well installation machine.

Typical installations use 400-800 ft of 8-inch diameter perforated recovery pipe (heavy-duty polyethylene tubing), normally installed with a double polyester filter (Fig. 8). A pumping riser extends from the recovery pipe to the surface. This pumping riser is normally either 8- or 10-inch PVC pipe, depending on well capacity. The end of the well opposite the pumping header is brought to the surface with nonperforated tubing. This cleanout end is normally capped, but it can also be used for pumping.

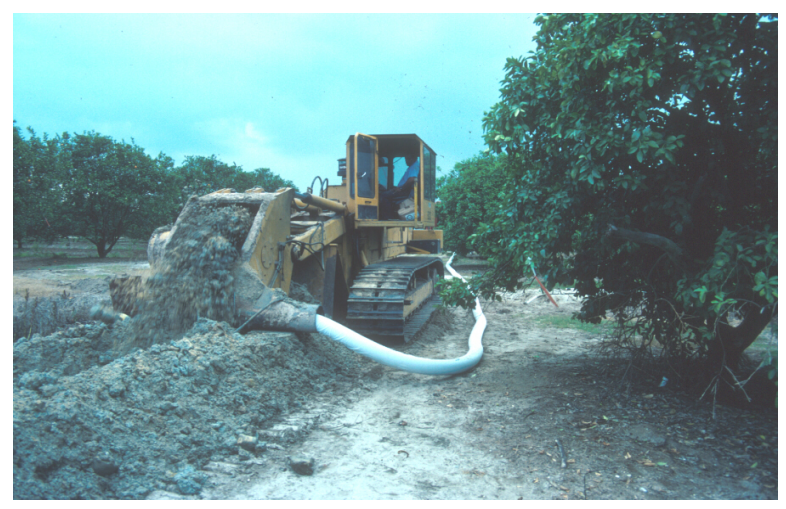

Figure 8. Horizontal well installation.

The actual well configuration is adaptable to the site conditions. Wells are installed at depths which are deemed most suitable from preliminary test and observation wells, which measure capacity and drawdown. Wells may be installed as "L" shaped, with the recovery tubing extending one direction from the pumping header, or as a "T" shape, with the recovery tubing extending in opposite directions from the header.

Multiple wells may be connected to a single riser to increase capacity or minimize drawdown. Wells normally use either submersible pumps (located in the PVC pumping riser) or aboveground centrifugal pumps, depending on pumping needs and user preferences. Well capacities vary widely, depending 
on user needs, recovery tubing length, pump horsepower, and the nature of the aquifer. Studies have shown that the extent of the water table depression and rate of recovery following pumping are dependent upon the rate at which the well is pumped. Sustained flow rates over 1,800 gpm have been achieved in some areas with single wells.

\section{References}

Boman, B.J. and D.R. Justice. 1992. Tapping shallow groundwater with horizontal wells, p. 45-50. In: E.T. Engman (ed.). Irrigation and drainage:

Saving a threatened resource - in search of solutions. Proc. ASCE Water Forum '92. ASCE, New York.

Clark, A.G. Smajstrla, F.S. Zazueta, F.T. Izuno, B. J. Boman, D.J. Pitts, and D.Z. Haman. 1993. Uses of water in Florida crop production systems. Univ. of Florida, IFAS Coop. Ext. Serv. Circ. 940.

Davies, F.S. and M.A. Maurer. 1993. Reclaimed wastewater for irrigation of citrus in Florida.

HortTechnology 3:163-167.

Fitzpatrick, E.A. 1974. An introduction to soil science. Longman Singapore, Singapore.

Graham, W.D. 1991. Florida's groundwater resource: Vast quantity, good quality? Univ. of Florida, IFAS Coop. Ext. Serv. Circ. 944.

Maurer, M.A. and F.S. Davies. 1993. Microsprinkler irrigation of young 'Redblush' grapefruit trees using reclaimed wastewater. HortScience 28:1157-1161. 